\title{
Article \\ Efficient Hydrogen Generation and Total Nitrogen Removal for Urine Treatment in a Neutral Solution Based on a Self-Driving Nano Photoelectrocatalytic System
}

\author{
Pengbo Wang ${ }^{1}$, Jinhua $\mathrm{Li}^{1, *}$, Yang Xu ${ }^{1}$, Changhui Zhou ${ }^{1}$, Yan Zhang ${ }^{1}$, Lina Zha ${ }^{1}$, Bo Zhang ${ }^{1}$, Jing Bai ${ }^{1,2}$ \\ and Baoxue Zhou ${ }^{1,2, *}$ \\ 1 Key Laboratory of Thin Film and Microfabrication Technology (Ministry of Education), \\ School of Environmental Science and Engineering, Shanghai Jiao Tong University, Shanghai 200240, China; \\ tianliangjue@sjtu.edu.cn (P.W.); xy0122@sjtu.edu.cn (Y.X.); zhouchanghui-sjtu@sjtu.edu.cn (C.Z.); \\ yan-zhang@sjtu.edu.cn (Y.Z.); zhalina_V5@sjtu.edu.cn (L.Z.); zhangb229@sjtu.edu.cn (B.Z.); \\ bai_jing@sjtu.edu.cn (J.B.) \\ 2 Shanghai Institute of Pollution Control and Ecological Security, Shanghai 200092, China \\ * Correspondence: lijinhua@sjtu.edu.cn (J.L.); zhoubaoxue@sjtu.edu.cn (B.Z.)
}

Citation: Wang, P.; Li, J.; Xu, Y.; Zhou, C.; Zhang, Y.; Zha, L.; Zhang, B.; Bai, J.; Zhou, B. Efficient Hydrogen Generation and Total Nitrogen Removal for Urine Treatment in a Neutral Solution Based on a Self-Driving Nano Photoelectrocatalytic System Nanomaterials 2021, 11, 2777. https:// doi.org/10.3390/nano11112777

Academic Editor: Detlef W. Bahnemann

Received: 24 September 2021 Accepted: 18 October 2021 Published: 20 October 2021

Publisher's Note: MDPI stays neutral with regard to jurisdictional claims in published maps and institutional affiliations.

Copyright: (c) 2021 by the authors. Licensee MDPI, Basel, Switzerland. This article is an open access article distributed under the terms and conditions of the Creative Commons Attribution (CC BY) license (https:// creativecommons.org/licenses/by/ $4.0 /)$.

\begin{abstract}
Urine is the main source of nitrogen pollution, while urea is a hydrogen-enriched carrier that has been ignored. Decomposition of urea to $\mathrm{H}_{2}$ and $\mathrm{N}_{2}$ is of great significance. Unfortunately, direct urea oxidation suffers from sluggish kinetics, and needs strong alkaline condition. Herein, we developed a self-driving nano photoelectrocatalytic (PEC) system to efficiently produce hydrogen and remove total nitrogen (TN) for urine treatment under neutral $\mathrm{pH}$ conditions. $\mathrm{TiO}_{2} / \mathrm{WO}_{3}$ nanosheets were used as photoanode to generate chlorine radicals $(\mathrm{Cl} \bullet)$ to convert urea-nitrogen to $\mathrm{N}_{2}$, which can promote hydrogen generation, due to the kinetic advantage of $\mathrm{Cl}^{-} / \mathrm{Cl} \bullet$ cyclic catalysis. Copper nanowire electrodes ( $\mathrm{Cu}$ NWs/CF) were employed as the cathode to produce hydrogen and simultaneously eliminate the over-oxidized nitrate-nitrogen. The self-driving was achieved based on a self-bias photoanode, consisting of confronted $\mathrm{TiO}_{2} / \mathrm{WO}_{3}$ nanosheets and a rear Si photovoltaic cell (Si PVC). The experiment results showed that hydrogen generation with $\mathrm{Cl} \bullet$ is 2.03 times higher than in urine treatment without $\mathrm{Cl} \bullet$, generating hydrogen at $66.71 \mu \mathrm{mol} \mathrm{h}{ }^{-1}$. At the same time, this system achieved a decomposition rate of $98.33 \%$ for urea in $2 \mathrm{~h}$, with a reaction rate constant of 0.0359 $\mathrm{min}^{-1}$. The removal rate of total nitrogen and total organic carbon (TOC) reached $75.3 \%$ and $48.4 \%$ in $2 \mathrm{~h}$, respectively. This study proposes an efficient and potential urine treatment and energy recovery method in neutral solution.
\end{abstract}

Keywords: nano photoelectrocatalysis; urine; hydrogen generation; self-driving; cyclic catalysis of $\mathrm{Cl}^{-} / \mathrm{Cl} \bullet$; total nitrogen removal

\section{Introduction}

Nitrogen pollution is the main cause of water eutrophication [1]. As high-concentration nitrogen-containing wastewater, billions of tons of urine are discarded every year, endangering human health [2,3]. Currently, urine contributes to $80 \%$ of the nitrogen and $10 \%$ of the COD load in municipal sewage [4,5]. Severe nitrogen overload has become the biggest challenge for existing wastewater treatment plants [6]. In order to meet the discharge standard of nitrogen and COD, a series of techniques are adopted including $\mathrm{A}^{2} \mathrm{O}$, chemical treatment and expanded hydraulic stay time [7], which greatly rise treatment time, floor area, and energy consumption. On the other hand, urea is an abandoned hydrogen source that has been ignored [8-11]. The thermodynamic decomposition of urea is only $39.95 \mathrm{~kJ}$ $\mathrm{mol}^{-1}$, which is $1 / 12$ of water splitting $474.38 \mathrm{~kJ} \mathrm{~mol}^{-1}$ (Equations (1) and (2)), indicating that urea is a suitable substitute for water splitting to produce $\mathrm{H}_{2}$ [12-14]. Therefore, 
decomposition of urea to $\mathrm{H}_{2}$ and simultaneous total nitrogen (TN) removal is an appealing solution for urine treatment [15].

$$
\begin{array}{ll}
2 \mathrm{H}_{2} \mathrm{O} \rightarrow 2 \mathrm{H}_{2}+\mathrm{O}_{2} & \Delta \mathrm{G}^{0}{ }_{1}=+474.38 \mathrm{~kJ} \mathrm{~mol}^{-1} \\
\mathrm{CO}\left(\mathrm{NH}_{2}\right)_{2}+\mathrm{H}_{2} \mathrm{O} \rightarrow \mathrm{CO}_{2}+\mathrm{N}_{2}+3 \mathrm{H}_{2} & \Delta \mathrm{G}^{0}{ }_{2}=+39.95 \mathrm{~kJ} \mathrm{~mol}^{-1}
\end{array}
$$

To solve the above problem, photoelectrocatalytic technology is a suitable method for processing urine [2]. However, the conversion of urea to $\mathrm{N}_{2}$ is a kinetic inert step with a high overpotential. Urea is more easily over-oxidized to nitrate, making it difficult to remove total nitrogen (TN), and available treatment technologies of nitrate are inefficient and expensive [16,17]. Moreover, urea oxidation reactions require strong alkaline conditions in most current research, which hinders the practical application of urine electrochemical treatment, due to faintly acidic actual urine, and alkali cost. Thus, transforming urea into $\mathrm{N}_{2}$ while simultaneously producing $\mathrm{H}_{2}$ in neutral solution is a challenging issue. Recently, chlorine radicals $(\mathrm{Cl} \bullet)$ have been considered as effective oxidant for the treatment of $\mathrm{NH}_{4}{ }^{+}$and amine wastewater, since it preferably reacts with electron-rich moieties through one-electron oxidation [18-22]. It has been confirmed that $\mathrm{Cl} \bullet$ can selectively react with ammonium or amino to form the main product $\mathrm{N}_{2}$, reducing the accumulation of nitrate and nitrite [23-25]. Chloride ions $\left(\mathrm{Cl}^{-}\right)$, as a common ion in urine, can be oxidized to $\mathrm{Cl} \bullet$ through strongly oxidative photogenerated holes under illumination [26]. Cl• converts urea to $\mathrm{N}_{2}$, with the formation of $\mathrm{Cl}^{-}$, which is oxidized into Cl• cyclically. Hydrogen generation is promoted since $\mathrm{Cl}^{-} / \mathrm{Cl} \bullet$ cyclic catalysis has a kinetic advantage with a singleelectron pathway, compared to direct urea oxidation. More importantly, there is no need to add additional alkali. Thus, the $\mathrm{Cl} \bullet$ generation reaction was introduced into this paper to remove $\mathrm{TN}$ for the urine treatments, and to generate $\mathrm{H}_{2}$ simultaneously.

Copper foam (CF) is considered to be a suitable cathode substrate aiming to produce $\mathrm{H}_{2}$, due to its large specific surface area, low lost, excellent conductivity, and stability [27-30]. CF can be improved to obtain a copper nanowire electrode (Cu NWs/CF) [31], which has a larger specific surface area, and an excellent rapid removal effect on nitrate and nitrite in a solution as a copper-based catalyst [32]. Subsequently, an improved Cu NWs/CF with more abundant active catalytic sites was used as cathode in this paper for $\mathrm{H}_{2}$ generation, and nitrate-nitrogen $\left(\mathrm{NO}_{3}{ }^{-}-\mathrm{N}\right)$ removal.

Inspired by these points, a self-driving nano photoelectrocatalytic (PEC) system was developed to efficiently produce $\mathrm{H}_{2}$ and remove TN for urine treatment under neutral $\mathrm{pH}$ conditions. $\mathrm{TiO}_{2} / \mathrm{WO}_{3}$ nanosheets, with high catalytic activity, stabilization, and visiblelight response due to the lattice matching and energy band alignment between $\mathrm{WO}_{3}$ and $\mathrm{TiO}_{2}$ [33], was used as photoanode to generate $\mathrm{Cl} \bullet$ and $\mathrm{HO} \bullet$ [34] for the conversion of ureanitrogen (Urea-N) to $\mathrm{N}_{2}$, and the enhancement of hydrogen generation [35], respectively. $\mathrm{Cu}$ NWs/CF were employed as the cathode to produce $\mathrm{H}_{2}$ and simultaneously eliminate the over-oxidized nitrate-nitrogen. The impressive results in $\mathrm{H}_{2}$ generation and $\mathrm{TN}$ removal also benefitted from the design of a self-bias photoanode, which consisted of confronted $\mathrm{TiO}_{2} / \mathrm{WO}_{3}$ nanosheets and a rear Si photovoltaic cell (Si PVC), in which the $\mathrm{TiO}_{2} / \mathrm{WO}_{3}$ mainly absorbed short-wavelength light and generated electron/hole pairs, and the Si PVC captured the filtered long-wavelength light and caused photovoltage, to highly promote the separation of photogenerated charges of the PEC system without the use of external voltage [36]. The results proved the synergistic effect of urea oxidation and $\mathrm{H}_{2}$ generation. Additionally, this PEC system could achieve rapid TN removal from urine, indicating that the system could realize urine rapid purification and energy recovery. Hence, this work proposes an efficient and promising method for urine $\mathrm{H}_{2}$ generation and $\mathrm{TN}$ removal.

\section{Materials and Methods}

2.1. Material and Chemicals

The reagents were purchased from China Sinopharm Chemical Reagent Co., Ltd. (Shanghai, China), and all chemicals were analytical grade. Milli-Q ultrapure water system 
was used to prepare deionized water. Si PVC was obtained from Suzhou XuNing Co., Ltd. (Suzhou, China). Fluorine-doped tin oxide (FTO) glass $\left(13 \Omega \mathrm{cm}^{-1}\right)$ was ordered from Nippon Sheet Glass Co., Ltd. (Tokyo, Japan). The CF (3 mm thickness) used as the substrate was purchased from Suzhou Taili Metal Foam Co., Ltd. (Suzhou, China).

\subsection{Preparation of the Electrodes}

Preparation of the $\mathrm{WO}_{3}$ nanosheets photoanode referred to the method found in previous research [37-39]. The $\mathrm{TiO}_{2} / \mathrm{WO}_{3}$ nanosheets photoanode was prepared through a hydrothermal method, on the basis of the $\mathrm{WO}_{3}$ photoanode [33]. During the process, the pre-prepared $\mathrm{WO}_{3}$ electrode was first placed aslant in an aqueous solution containing $10 \mathrm{mmol} \mathrm{L}{ }^{-1}$ ammonium fluorotitanate and $75 \mathrm{mmol} \mathrm{L}^{-1}$ boric acid, with a constant temperature of $40^{\circ} \mathrm{C}$ for $8 \mathrm{~h}$, and the $\mathrm{TiO}_{2} / \mathrm{WO}_{3}$ photoanode was subsequently prepared after a rinsing and drying process. A Si PVC rear photoanode was connected in series with the front $\mathrm{TiO}_{2} / \mathrm{WO}_{3}$ photoanode, and sealed by epoxy resin.

The $\mathrm{Cu}$ NWs/CF was synthesized in the following successive sequence: alkaline oxidation [40], high temperature dehydration, and electroreduction methods [31]. In detail, a piece of CF $(2 \mathrm{~cm} \times 5 \mathrm{~cm})$ was first placed in an aqueous solution containing $2.5 \mathrm{~mol} \mathrm{~L}^{-1}$ sodium hydroxide and $0.125 \mathrm{~mol} \mathrm{~L}^{-1}$ sodium persulfate for 4 min to obtain $\mathrm{Cu}(\mathrm{OH})_{2}$ nanowire electrodes. Secondly, a pre-prepared $\mathrm{Cu}(\mathrm{OH})_{2}$ nanowire electrode was annealed at $180{ }^{\circ} \mathrm{C}$ for $180 \mathrm{~min}$ to obtain $\mathrm{CuO}$ nanowire electrodes. Thirdly, the $\mathrm{CuO}$ nanowire electrode was reduced in a typical three-electrode system for $30 \mathrm{~min}$ at $-1 \mathrm{~V}$ (vs. $\mathrm{Ag} / \mathrm{AgCl}$ ) with $1 \mathrm{~mol} \mathrm{~L}^{-1} \mathrm{Na}_{2} \mathrm{SO}_{4}$. After washing and drying, a $\mathrm{Cu} \mathrm{NWs} / \mathrm{CF}$ electrode was finally prepared.

\subsection{Experimental Setup}

The reactor of the PEC system in this study was a single chamber reactor under a simulated solar light (100 $\left.\mathrm{mW} \mathrm{cm}^{-2}\right)$, using a $350 \mathrm{~W}$ Xe lamp (Perfect, Shanghai, China). The electrolyte contained $50 \mathrm{mmol} \mathrm{L}{ }^{-1} \mathrm{Na}_{2} \mathrm{SO}_{4}$, a certain concentration of urea, and a certain concentration of $\mathrm{Cl}^{-}$, with a volume of $25 \mathrm{~mL}$. The immersion area of the $\mathrm{TiO}_{2} / \mathrm{WO}_{3}$ photoanode and the copper nanowire counter electrode was $4 \mathrm{~cm}^{2}(2 \mathrm{~cm} \times 2 \mathrm{~cm})$, and the distance between the electrodes was $1.5 \mathrm{~cm}$. The composition of synthetic urine is described in Table S1. Actual urine was obtained from 5 healthy volunteers. An electrochemical workstation was connected between the photoanode and the counter electrode to monitor the current, and to regulate voltage. Samples were taken out every $30 \mathrm{~min}$ for component analysis during the two-hour reaction process. The $\mathrm{TN}$ removal rate was calculated by dividing the final TN concentration by the initial TN concentration. All experiments were repeated at least three times to ensure the credibility of the data and results.

\subsection{Analytical Methods}

A scanning electron microscope (SEM) (SUPRA55-VP, Zeiss, Oberkochen, Germany) equipped with an X-ray energy dispersive spectrometer was used to scan the surface of electrodes. Phase composition of electrodes were investigated through X-ray diffraction (XRD, D-Max B, Rigaku, Tokyo, Japan) and X-ray photoelectron spectroscopy (XPS, EA125, Omicron, Vienna, Austria), using XPSPEAK to fit XPS data. The absorption spectra were measured using a UV-visible spectrophotometer (TU-1901, Pgeneral, Beijing, China). A UV-visible spectrophotometer (TU-1810, Persee, Beijing, China) was used to monitor the concentration of ammonia-nitrogen in the solution at $420 \mathrm{~nm}$, colored using potassium sodium tartrate and Nessler reagent after diluting 10 times. Ion chromatography (ICS-1000, Dionex, San Francisco, CA, USA) was used to determine nitrate-nitrogen and nitrite-nitrogen $\left(\mathrm{NO}_{2}{ }^{-}-\mathrm{N}\right)$ content. The conditions of ion chromatography were as follows: the sample solution was purified by an IC Na column, and the chromatographic column was an IonPac AS23 $4 \mathrm{~mm} \times 250 \mathrm{~mm}$ ion exchange column with $5.0 \mathrm{mmol} / \mathrm{L} \mathrm{Na}_{2} \mathrm{CO}_{3}$ and $0.2 \mathrm{mmol} / \mathrm{L} \mathrm{NaHCO}_{3}$ eluent, at a flow rate of $1.0 \mathrm{~mL} / \mathrm{min}$. The concentration of urea was detected through the high-performance liquid chromatography method (HPLC-2010Plus, 
Shimadzu, Osaka, Japan). The conditions of HPLC were as follows: chromatographic column: Kromasil 100- $\mathrm{NH}_{2}$ column $(250 \mathrm{~mm} \times 4.6 \mathrm{~mm}, 5 \mu \mathrm{m})$; eluent: acetonitrile-water (90:10); flow rate: $1.0 \mathrm{~mL} / \mathrm{min}$; column temperature: $30^{\circ}$. The electrochemical workstation was used to perform linear sweep voltammetry (LSV) (sweep speed $0.02 \mathrm{~V} / \mathrm{s}$ ), electrochemical impedance spectroscopy, and test the photoelectric performance of the prepared photoanode and monitor the system current. The concentration of total organic carbon (TOC) and TN were monitored by a TOC/TN analyzer (Multi-3100, Analytikjena, Jena, Germany). The type of free radicals was tested using electron spin resonance spectrometer (EPR, Bruker, Billerica, MA, USA) [41]. $\mathrm{H}_{2}$ generation was determined using PerfectLight Labsolar 6A (PerfectLight, Beijing, China) and Fuli GC9790 Plus (Fuli, Taizhou, China).

\section{Results and Discussion}

\subsection{Characterization of the Electrodes}

Figure $1 \mathrm{a}$,b shows the SEM images of the $\mathrm{WO}_{3}$ nanosheets and the $\mathrm{TiO}_{2} / \mathrm{WO}_{3}$ nanosheets electrode, respectively. The $\mathrm{WO}_{3}$ nanosheets were vertically and crosswise grown on the entire FTO substrate. The size of each $\mathrm{WO}_{3}$ nanosheet was approximately $2 \mu \mathrm{m} \times 1.5 \mu \mathrm{m} \times 0.4 \mu \mathrm{m}$. Similar frameworks were observed in $\mathrm{WO}_{3}$ and $\mathrm{TiO}_{2} / \mathrm{WO}_{3}$. There appears no significant morphological change to the nanosheet after modification with $\mathrm{TiO}_{2}$, but small thorns can be observed, suggesting the successful growth of $\mathrm{TiO}_{2}$. $\mathrm{TiO}_{2}$ thorns were densely and evenly grown on the entire surface of the $\mathrm{WO}_{3}$ nanosheets, which protected and passivated $\mathrm{WO}_{3}$. Accordingly, the modified $\mathrm{TiO}_{2}$ layer not only increased the photo-response current but also enhanced the stability of $\mathrm{WO}_{3}$, due to surface passivation (Figure $\mathrm{S} 1$ ). In addition, the light absorption spectrum of $\mathrm{TiO}_{2} / \mathrm{WO}_{3}$ slightly expanded from $407 \mathrm{~nm}$ to $417 \mathrm{~nm}$, compared to the bare $\mathrm{WO}_{3}$ (Figure S2), indicating a better absorption of visible light. The phase composition of the samples was investigated using XRD method, which verified the formation of $\mathrm{WO}_{3}$ on $\mathrm{FTO}$, whereas no typical peaks of $\mathrm{TiO}_{2}$ were detected, due to the thin $\mathrm{TiO}_{2}$ layer (Figure S3a). The characteristic peaks of $\mathrm{WO}_{3}$ corresponded with a monoclinic crystalline phase (JCPDS no. 43-1035), which was verified to have an excellent photoelectric performance in comparison to other crystalline phases, due to high activity and stability [42]. XPS analysis further demonstrated the existence of $\mathrm{TiO}_{2}$ according to the typical peaks at $459.27 \mathrm{eV}$ and $464.96 \mathrm{eV}$, which are assigned to Ti2 $\mathrm{p}_{3 / 2}$ and Ti2 $\mathrm{p}_{1 / 2}$, respectively (Figure S3b) [43].

Figure 1c,d shows the SEM images of the CF and the Cu NWs/CF electrodes, respectively. The $\mathrm{CF}$ has a frame structure of $400 \mu \mathrm{m}$ micro-pores in diameter. A smooth surface was seen on the bare $\mathrm{CF}$, which limited the specific surface area; in contrast, the surface became rough and porous after surface treatment (Figure 1d). A large number of nanowire structures were grown resembling a bird's nest throughout the whole surface of the $\mathrm{CF}$, showing a larger specific surface area, and the diameter of the nanowires was approximately $150 \mathrm{~nm}$, according to the TEM image of Figure S4. According to the results of the confocal laser scanning microscope, the surface roughness of $\mathrm{Cu}$ NWs/CF was almost six times that of $\mathrm{CF}$, increasing from $0.28 \mu \mathrm{m}$ to $1.60 \mu \mathrm{m}$ (Figure S5). In order to properly understand the formation of the $\mathrm{Cu}$ nanowires, we analyzed the XRD patterns of samples at different fabrication stages. As shown in Figure S6a, the typical 020, 021, 040, 130, and 150 crystal planes were detected at $16.5^{\circ}$ and $23.4^{\circ}, 33.7^{\circ}, 39.6^{\circ}$, and $53.1^{\circ}$, respectively, indicating the formation of $\mathrm{Cu}(\mathrm{OH})_{2}$ nanowires after alkaline oxidation [44,45]. After calcination and electro-reduction, the $\mathrm{Cu}(\mathrm{OH})_{2}$ crystal planes disappeared, and only copper peaks remained. The XPS method was used to further analyze the composition of the $\mathrm{Cu}$ NWs/CF. On the $\mathrm{Cu}$ NWs/CF (Figure S6b), the difference between the peaks at $932.3 \mathrm{eV}$ and $952.1 \mathrm{eV}$ was $19.8 \mathrm{eV}$, which represented the $\mathrm{Cu} 2 \mathrm{p}_{3 / 2}$ and $\mathrm{Cu} 2 \mathrm{p}_{1 / 2}$ peaks of $\mathrm{Cu}^{0}$, confirming the existence of elemental copper [46]. There was also a small amount of $\mathrm{Cu}^{2+}$ in the sample, which was possibly due to inadequate electroreduction or natural air oxidation. After electroreduction and growth of the $\mathrm{Cu}$ nanowires, the purity of the elemental copper was greatly increased (Figure S6c). As can be seen in Figure S7a, the impedance reduced greatly after the growth of $\mathrm{Cu}$ nanowires on $\mathrm{CF}$. Moreover, the current of 
$\mathrm{Cu}$ NWs/CF was 1.9 times higher than that of pristine $\mathrm{CF}$ at a $1.2 \mathrm{~V}$ potential, which indicated that $\mathrm{Cu}$ NWs/CF was more conducive to hydrogen generation (Figure $\mathrm{S} 7 \mathrm{~b}$ ).
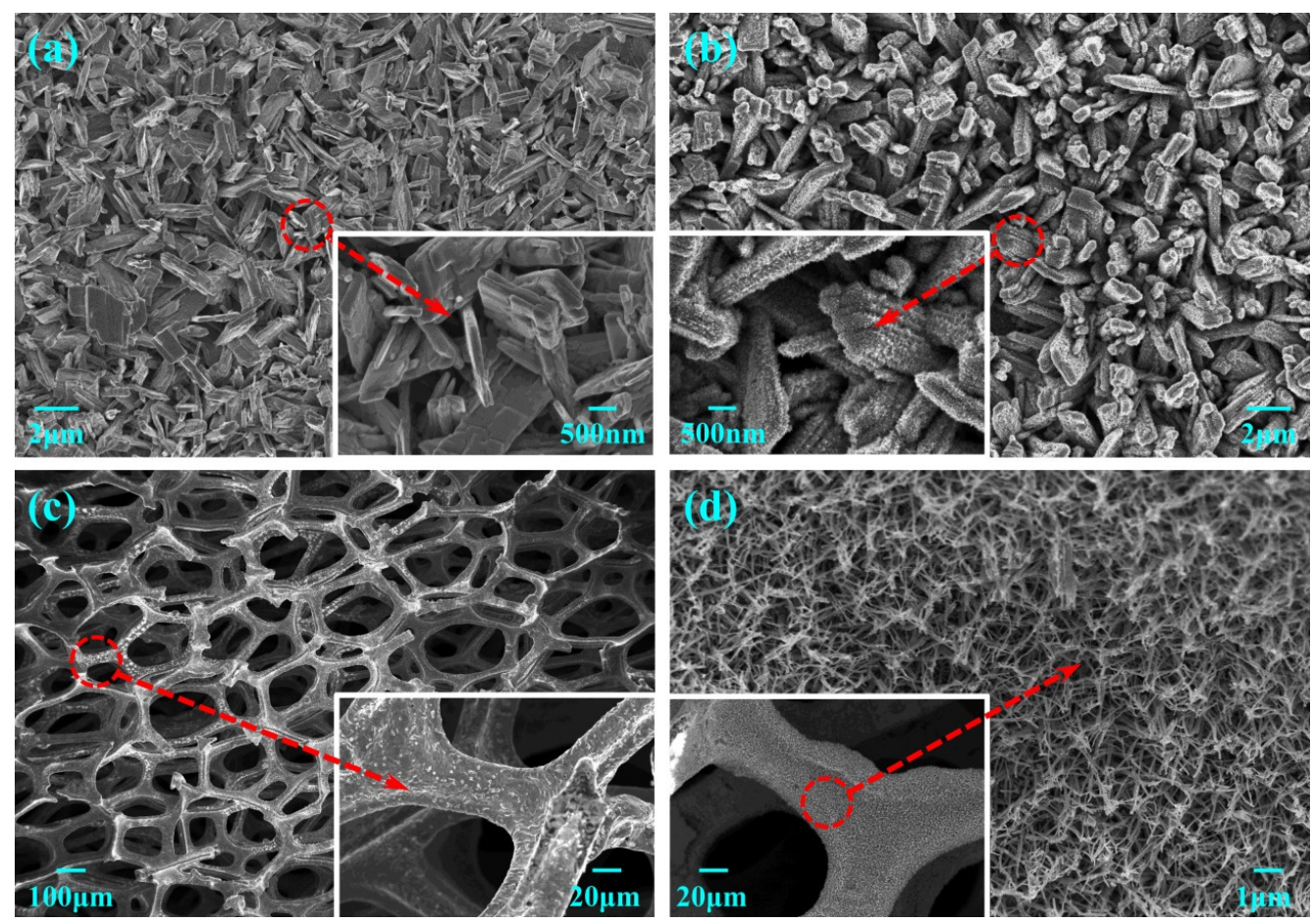

Figure 1. SEM images of the (a) $\mathrm{WO}_{3} ;$ (b) $\mathrm{TiO}_{2} / \mathrm{WO}_{3} ;$ (c) $\mathrm{CF}$; and (d) $\mathrm{Cu}$ NWs $/ \mathrm{CF}$ electrodes.

\subsection{Hydrogen Generation and Total Nitrogen Removal}

Figure 2a shows the schematic diagram of the self-bias composite photoanode and $\mathrm{Cu}$ NWs/CF cathode-based PEC system. Cu NWs/CF was employed as the cathode to produce $\mathrm{H}_{2}$, and to simultaneously eliminate the over-oxidized nitrate-nitrogen. $\mathrm{TiO}_{2} / \mathrm{WO}_{3}$ was used as the front photoanode material to generate $\mathrm{Cl} \bullet$ and $\mathrm{HO} \bullet$ for the conversion of urea-nitrogen to $\mathrm{N}_{2}$ and the degradation of organic matter, respectively. Si PVC was applied as the rear photoanode to promote the separation of photogenerated charges. As shown in Figure $2 \mathrm{~b}, \mathrm{TiO}_{2} / \mathrm{WO}_{3}$ utilized sunlight with a wavelength of less than $460 \mathrm{~nm}$, and sunlight with a wavelength of more than $460 \mathrm{~nm}$, which passed through $\mathrm{TiO}_{2} / \mathrm{WO}_{3}$, was utilized by Si PVC. Si PVC was attached to the back of the $\mathrm{TiO}_{2} / \mathrm{WO}_{3}$, and was sealed as a composite photoanode by silicone rubber to fully utilize the sunlight. $\mathrm{TiO}_{2} / \mathrm{WO}_{3}$ produced photogenerated holes and electrons, and the internal electric field provided by $\mathrm{Si}$ PVC transferred photo-generated electrons to the $\mathrm{Cu}$ NWs/CF cathode, prolonging the life of the photo-generated holes, and promoting the $\mathrm{H}_{2}$ production. Synthetic urine, as a test sample that was compounded according to Table S1 (including $0.266 \mathrm{~mol} \mathrm{~L}^{-1}$ urea), was used to investigate the $\mathrm{H}_{2}$ generation and TN removal from urine. The contents of the blank group and the treatment group are shown in Table S2. Figure 2c shows the $\mathrm{H}_{2}$ generation through using the PEC system with and without $\mathrm{Cl} \bullet$. Hydrogen generation with $\mathrm{Cl} \bullet$ is 2.03 times greater than without $\mathrm{Cl} \bullet$, generating hydrogen at $66.71 \mu \mathrm{mol} \mathrm{h}^{-1}$, since the $\mathrm{Cl} \bullet$ evolution reaction (ClER) has a kinetic advantage, and $\mathrm{Cl} \bullet$ has been verified to promote the oxidation of urea [47]. It should be noted that urea and $\mathrm{Cl}^{-}$are both indispensable for highly efficient $\mathrm{H}_{2}$ generation. Without urea, $\mathrm{H}_{2}$ generation had a downtrend during the degradation process. The reason for this was that, although $\mathrm{Cl} \bullet$ was produced, there was no reactant, such as urea, reacting with $\mathrm{Cl} \bullet$, and the $\mathrm{Cl}^{-}-\mathrm{Cl} \bullet$ cycle could not be realized, which showed the importance of urea. Urea and $\mathrm{Cl}^{-}$cooperate to promote $\mathrm{H}_{2}$ production under neutral $\mathrm{pH}$ conditions. 

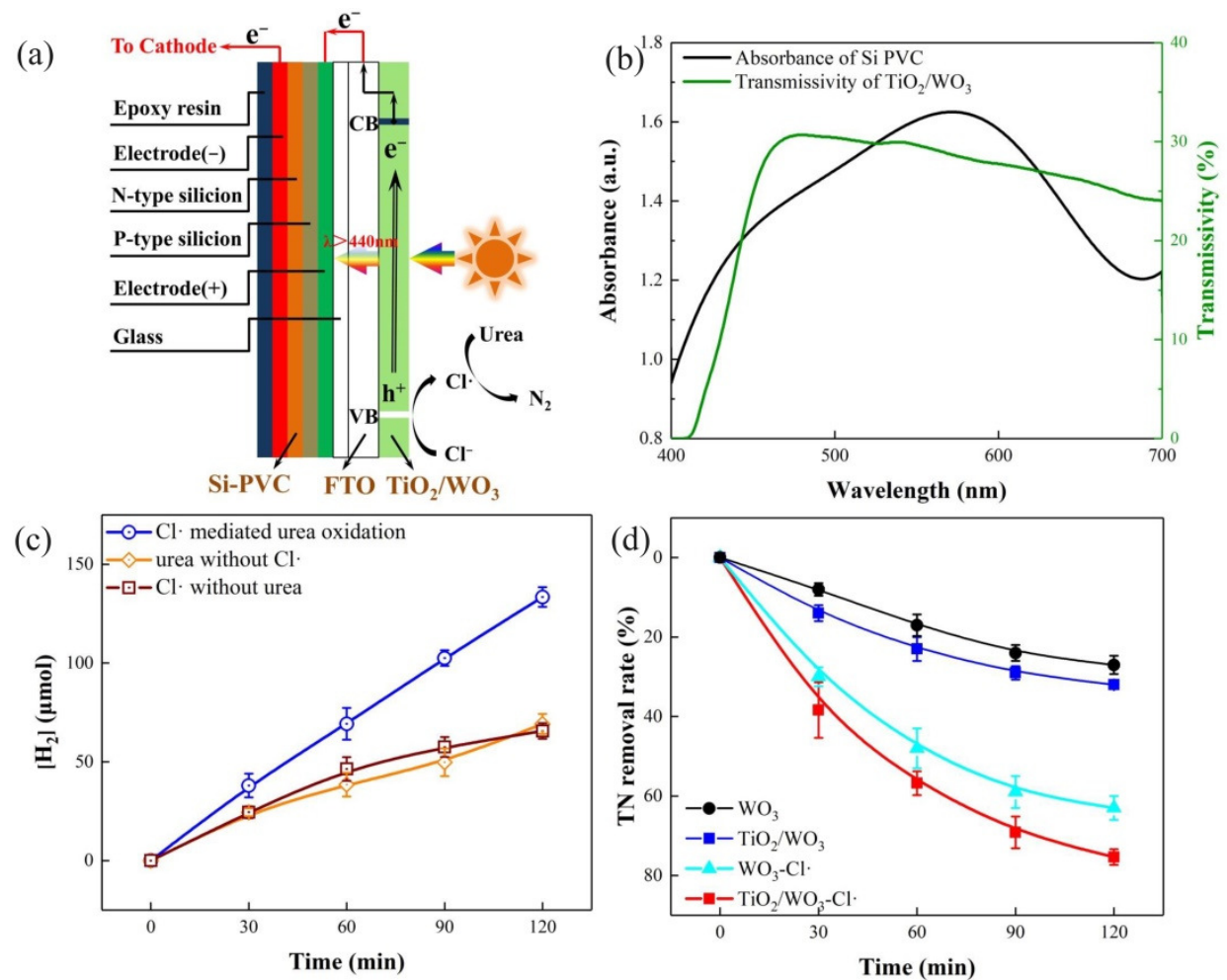

Figure 2. (a) Schematic diagram of $\mathrm{TiO}_{2} / \mathrm{WO}_{3} / \mathrm{Si} \mathrm{PVC}$ composite photoanode; (b) absorbance of Si PVC and transmissivity of $\mathrm{TiO}_{2} / \mathrm{WO}_{3}$ electrode; (c) hydrogen generation under different conditions; (d) TN removal rate during a $2 \mathrm{~h}$ operation under different conditions. Conditions: $20 \mathrm{mg} \mathrm{L}^{-1}$ urea; $50 \mathrm{mmol} \mathrm{L}^{-1} \mathrm{Na}_{2} \mathrm{SO}_{4} ; 75 \mathrm{mmol} \mathrm{L}-1 \mathrm{NaCl}$; solution $\mathrm{pH}=7$.

Figure $2 \mathrm{~d}$ shows that the system can also achieve TN removal from urine. The TN removal rate was obviously much slower in the absence of $\mathrm{Cl} \bullet$. The performance of the $\mathrm{TiO}_{2} / \mathrm{WO}_{3}$ photoanode is superior compared to the $\mathrm{WO}_{3}$ photoanode, due to better light response and stability (Figure S1). Urea was rapidly and completely degraded with a removal rate of $98.33 \%$, and a reaction rate constant of $0.0359 \mathrm{~min}^{-1}$ (Figure S8). The TN removal rate reached $75.3 \%$ after a $2 \mathrm{~h}$ operation under optimal conditions, with almost only nitrate-nitrogen left, and after a $4 \mathrm{~h}$ operation, the TN removal rate reached $90.2 \%$ due to a continuous reduction of nitrate-nitrogen on the cathode. The TOC removal rate also can reach $48.4 \%$ in $2 \mathrm{~h}$, and $56.0 \%$ in $4 \mathrm{~h}$ (Figure S9). Figure S10 showed the variation of different nitrogen species during the decomposition of urea. As can be seen, the concentration of nitrite-nitrogen and ammonia-nitrogen was fairly small, whereas the nitrate-nitrogen clearly appeared after a $60 \mathrm{~min}$ reaction. As the reaction continued, the concentration of nitrate nitrogen gradually decreased, indicating that most of the nitrogen in the urea had been converted to $\mathrm{N}_{2}$. The reason can be attributed to an exhausted conversion of soluble nitrogen species to $\mathrm{N}_{2}$, with the synergistic function of the $\mathrm{Cl} \bullet$ radicals and the $\mathrm{Cu} N \mathrm{NW} / \mathrm{CF}$ electrode; this will be further discussed below. Overall, this system achieved excellent TN removal from urine, and simultaneous $\mathrm{H}_{2}$ energy recovery under neutral $\mathrm{pH}$ conditions.

\subsection{Influence Factors}

\subsubsection{Effect of Cathode Type}

The function of the cathode in this system is to generate $\mathrm{H}_{2}$, and eliminate the trace nitrate produced by the excessive oxidation of urea in the photoanode area. The $\mathrm{Cu}$ NWs/CF had an excellent performance, especially concerning $\mathrm{H}_{2}$ generation, which was verified by experiments. Figure 3 a shows the $\mathrm{H}_{2}$ generation and nitrogen removal by using $\mathrm{Cu}$ NWs/CF, and three common electrodes (copper foil, $\mathrm{CF}$, and platinum foil electrode), respectively (immersion area of $4 \mathrm{~cm}^{2}$ ). After a $2 \mathrm{~h}$ reaction, the $\mathrm{H}_{2}$ production rates were $68.47,77.16,94.50$, and $139.06 \mu \mathrm{mol}$, and the $\mathrm{TN}$ removal rates were $14.49 \%, 35.2 \%$, 
$51.57 \%$, and $75.30 \%$ for copper foil, CF, platinum electrodes, and Cu NWs/CF, respectively, suggesting that $\mathrm{Cu}$ NWs /CF was significantly better than the other three electrodes. We designed an experiment to compare the reduction rate of nitrate by using four electrodes; Figure S11 shows that the nitrate reduction performance of Cu NWs/CF is obviously better than the other three electrodes. Although the platinum electrode is expensive, it has good nitrogen removal rates and $\mathrm{H}_{2}$ generation effects. However, compared with the expensive platinum electrode, the $\mathrm{H}_{2}$ generation of $\mathrm{Cu} \mathrm{NWs} / \mathrm{CF}$ increased by $47.15 \%$, and the two-hour TN removal rate also increased from $51.57 \%$ to $75.30 \%$. Calculating the cost of platinum electrode versus $\mathrm{Cu} N \mathrm{NW} / \mathrm{CF}$, the production cost per unit area of $\mathrm{Cu}$ $\mathrm{NWs} / \mathrm{CF}$ is only $0.2 \%$ of that of platinum electrode. The reason for the high current density and excellent denitrification effect of the $\mathrm{Cu}$ NWs/CF electrodes is the specific surface area and active site of the three-dimensional structure, which greatly accelerates electron transport, and obtains a higher current density. Therefore, under the same conditions, only $\mathrm{Cu}$ NWs/CF could achieve rapid TN removal and large amounts of $\mathrm{H}_{2}$ generation with low cost.
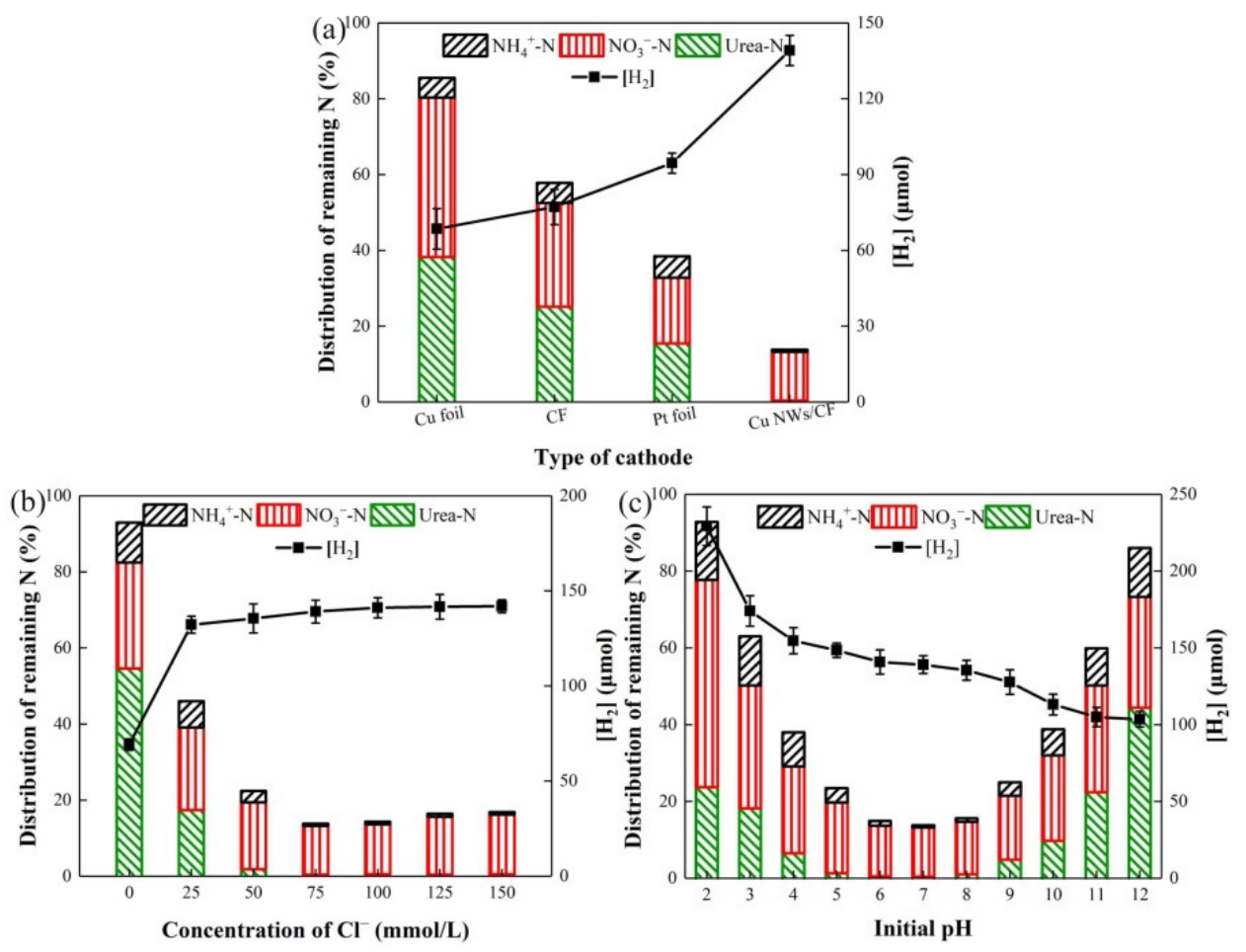

Figure 3. Effect of (a) cathode type; (b) $\mathrm{Cl}^{-}$concentration; and (c) initial $\mathrm{pH}$ upon hydrogen generation and $\mathrm{TN}$ removal. Conditions: urea $20 \mathrm{mg} \mathrm{L}^{-1} ; 50 \mathrm{mmol} \mathrm{L}^{-1} \mathrm{Na}_{2} \mathrm{SO}_{4}$.

\subsubsection{Effect of $\mathrm{Cl}^{-}$Concentration}

The concentration of $\mathrm{Cl}^{-}$directly affects the denitrification of urine and $\mathrm{H}_{2}$ generation. Figure $3 \mathrm{~b}$ shows the proportion of the remaining nitrate-nitrogen, ammonia-nitrogen, and urea-nitrogen, as well as the related hydrogen generation after a $2 \mathrm{~h}$ reaction, when the $\mathrm{Cl}^{-}$concentration was $0,25,50,75,100,125$, and $150 \mathrm{mmol} \mathrm{L}^{-1}$, respectively. The result showed that the TN removal rate rapidly increased once $\mathrm{Cl}^{-}$was added, indicating that $\mathrm{Cl}^{-}$played an essential role in the degradation of urea. The most suitable $\mathrm{Cl}^{-}$concentration for TN removal was $75 \mathrm{mmol} \mathrm{L}^{-1}$, when urea was completely degraded with the smallest remaining amounts of nitrate-nitrogen and ammonia-nitrogen, and the TN removal rate reached $75.3 \%$. When the $\mathrm{Cl}^{-}$concentration was higher than $75 \mathrm{mmol} \mathrm{L}^{-1}$, although urea was completely oxidized, the remaining nitrate-nitrogen increased, which indicated that a denitrification effect would be slightly restrained when $\mathrm{Cl}^{-}$concentration was extremely high. When the $\mathrm{Cl}^{-}$concentration was lower than $75 \mathrm{mmol} \mathrm{L}^{-1}$, a part of the urea remained, 
with large amounts of nitrate and ammonium left. Correspondingly, the $\mathrm{H}_{2}$ generation increased by 1.93 times after adding $75 \mathrm{mmol} \mathrm{L}^{-1} \mathrm{Cl}^{-}$; however, it remains relatively stable with a further increase of $\mathrm{Cl}^{-}$concentration. Considering both the $\mathrm{H}_{2}$ generation and TN removal, the optimal $\mathrm{Cl}^{-}$concentration herein is suggested to be $75 \mathrm{mmol} \mathrm{L}^{-1}$.

\subsubsection{Effect of Initial $\mathrm{pH}$}

Solution $\mathrm{pH}$ has a significant impact on urine $\mathrm{TN}$ removal by affecting the performance of the electrodes and oxidation-reduction reaction in the solution. The $\mathrm{H}_{2}$ generation and TN removal effect at $\mathrm{pH} 2-12$ were investigated. The result is shown in Figure 3c. For $\mathrm{H}_{2}$ generation, the overall trend was that $\mathrm{H}_{2}$ generation increased with the decrease of $\mathrm{pH}$; however, when the solution atmosphere was over-acid, the TN removal effect of urine and the stability of the electrode system was affected. Neutral $\mathrm{pH}$ conditions are most conducive to TN removal. When the $\mathrm{pH}$ was between $5-8$, most of the urea was degraded; in contrast, when the solution $\mathrm{pH}$ was over-acid or over-alkaline, part of the urea remained, with large amounts of nitrate-nitrogen and ammonia-nitrogen left behind [48]. under the condition of overacidity, reducibility of the system was motivated by high concentration of $\mathrm{H}^{+}$, resulting in an accumulation of ammonium. At the same time, $\mathrm{H}^{+}$competed for electronics with nitrate at the cathode, leading to accumulation of nitrate-nitrogen. Similarly, In the condition of over-alkalinity, the oxidability of the system promoted the formation of nitrate-nitrogen. In addition, the HO• potential was shifted negatively in comparison to $\mathrm{Cl} \bullet$; thus the proportion of $\mathrm{HO} \bullet$ increased and the proportion of $\mathrm{Cl} \bullet$ decreased, which affected the selective oxidation of ammonium and urea to $\mathrm{N}_{2}$, resulting in the accumulation of nitrate-nitrogen. Furthermore, the $\mathrm{TiO}_{2} / \mathrm{WO}_{3}$ and $\mathrm{Cu}$ NWs $/ \mathrm{CF}$ have the best stability at neutral $\mathrm{pH}$. The performance of the $\mathrm{TiO}_{2} / \mathrm{WO}_{3}$ photoanode was affected under the condition of over-alkalinity, which reduced the number of radicals in the system and weakened the degradation of urea. The nanowire fractures of $\mathrm{Cu}$ NWs/CF were corroded under the condition of overacidity, with the specific surface area reduced, which affected the reduction of nitrate. Hence, in order to ensure good urine TN removal effect and simultaneous $\mathrm{H}_{2}$ generation, a $\mathrm{pH}$ of 7 should be the optimal condition, which is consistent with the theme of this work.

\subsection{Mechanism of Hydrogen Generation and TN Removal}

In order to explore the mechanism of $\mathrm{H}_{2}$ generation and urine $\mathrm{TN}$ removal in the PEC system, we first examined the free radicals ( $\mathrm{HO} \bullet$ or $\mathrm{Cl} \bullet$ ) through an EPR spectra, using 5,5-Dimethyl-1-pyrroline N-oxide (DMPO) as a trapping agent. As can be seen in Figure $4 \mathrm{a}$, four equidistant peaks of DMPO-HO• with an intensity of 1:2:2:1 were observed without $\mathrm{Cl}^{-}$, while another seven-line signals corresponding to DMPO-Cl• were detected with $\mathrm{Cl}^{-}$[49]. Afterwards, free radical-quenching experiments were carried out [50]. Two kinds of free radical quencher were used to investigate the function of $\mathrm{HO} \bullet$ and $\mathrm{Cl} \bullet$ in the reaction process. As is well known, tert-butanol quenches both $\mathrm{HO} \bullet$ and $\mathrm{Cl} \bullet$, and p-chlorobenzoic acid only quenches HO•. Therefore, as shown in Figure $4 b$, after adding 10 mmol L ${ }^{-1}$ tert-butanol into the solution, the removal rate of TN was remarkably reduced to $15.38 \%$. However, the removal rate of $\mathrm{TN}$ was still as high as $62.93 \%$ when using $\mathrm{p}$ chlorobenzoic acid. The experiment result showed that, when there was only $\mathrm{Cl} \bullet$ in the solution, the TN removal effect was still positive, indicating that $\mathrm{Cl} \bullet$ can be catalyst of urine denitrification without $\mathrm{HO} \bullet$. On the other hand, when $\mathrm{Cl}^{-}$was not added to the system, a part of urea, nitrate-nitrogen, and ammonia-nitrogen remained in the solution after the reaction (Figure $3 \mathrm{~b}$ ), which further illustrated the strong function of $\mathrm{Cl} \bullet$. Therefore, $\mathrm{Cl} \bullet$ plays a pivotal role in the TN removal process. 

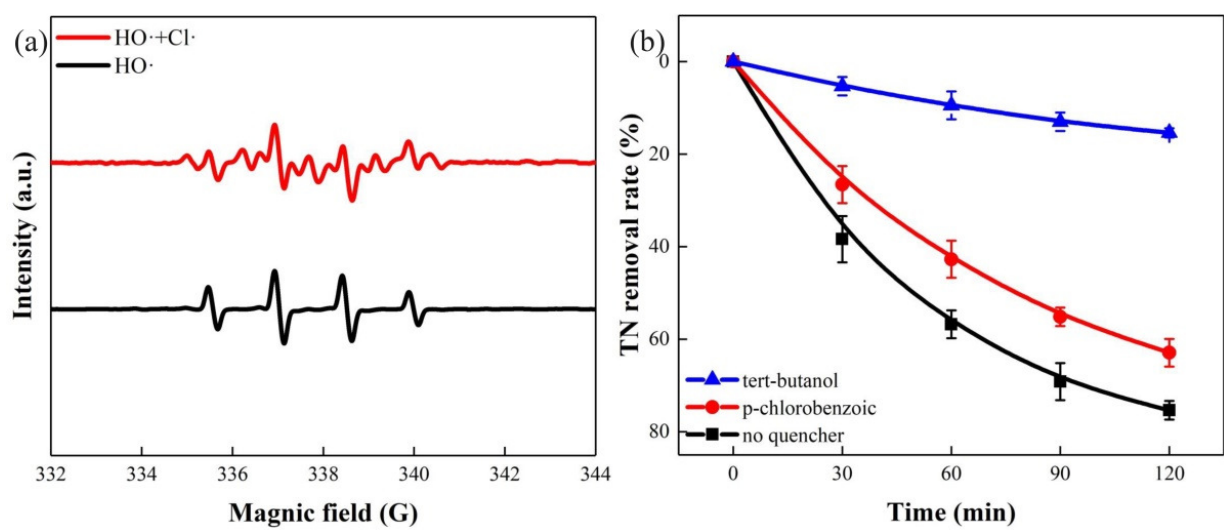

Figure 4. (a) EPR spectra of radicals with and without $\mathrm{NaCl}$; (b) free radical quenching experiment. Conditions: $20 \mathrm{mg} \mathrm{L}^{-1}$ urea; $50 \mathrm{mmol} \mathrm{L}^{-1} \mathrm{Na}_{2} \mathrm{SO}_{4} ; 75 \mathrm{mmol} \mathrm{L}-1 \mathrm{NaCl}$; solution $\mathrm{pH}=7$.

According to the research conclusion in this section, the possible TN removal process of urine in this system was inferred (Figure 5). Under the excitation of sunlight, photogenerated hole-electron pairs were generated on the $\mathrm{TiO}_{2} / \mathrm{WO}_{3}$ photoanode (Equation (3)). The photo-generated holes with strong oxidizing properties could promote the generation of free radicals ( $\mathrm{HO} \bullet$ and $\mathrm{Cl} \bullet$ ) in the solution (Equations (4)-(6)). Urea molecules were rapidly oxidized and degraded by $\mathrm{HO} \bullet$ and $\mathrm{Cl} \bullet$. The difference was that $\mathrm{Cl} \bullet$ can selectively oxidize urea/ammonium to $\mathrm{N}_{2}$, while $\mathrm{HO} \bullet$ oxidized urea/ammonium to $\mathrm{NO}_{3}{ }^{-}$(Equations (7)-(10)), which was proven in Figures $3 \mathrm{~b}$ and 4 . The unavoidable $\mathrm{NO}_{3}{ }^{-}$produced at the anode was reduced to $\mathrm{N}_{2}$ or ammonium in the Cu NWs/CF (Equations (11) and (12)), and ammonium was oxidized to $\mathrm{N}_{2}$ in the anode area once again. Repeated cyclic reactions led to the removal of TN.

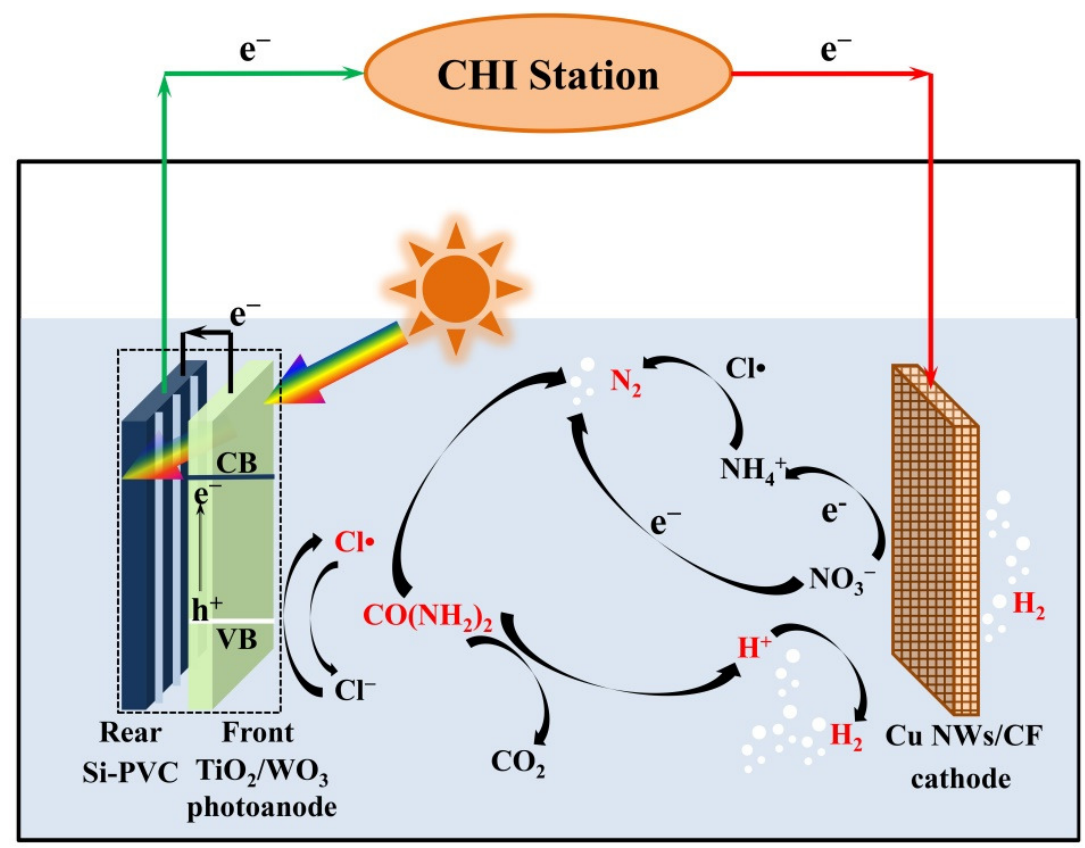

Figure 5. Device schematic diagram and working mechanism of the self-driving PEC system.

For the mechanism of $\mathrm{H}_{2}$ generation, $\mathrm{Cl}^{-}$and urea collaboratively promoted to produce $\mathrm{H}_{2}$. According to the result in Figure $2 \mathrm{c}, \mathrm{Cl}^{-}$and urea were both indispensable. In the PEC system, there are oxygen evolution reactions (OERs) and ClERs in the photoanode area. Four electrons are involved in the OER, whereas only one electron is involved in the ClER, which gives the $\mathrm{ClER}$ a kinetic advantage. As such, the addition of $\mathrm{Cl}^{-}$could raise the current density and $\mathrm{H}_{2}$ generation. However, with a limited amount of $\mathrm{Cl}^{-}$, after all of the $\mathrm{Cl}^{-}$was oxidized 
to $\mathrm{Cl} \bullet$, the current density decreased again. As can be seen in Figure 2c, by simply adding $\mathrm{Cl}^{-}$into the solution, hydrogen production tended to increase in the first half of the reaction, while decreasing in the second half. This problem could be solved by urea, since urea reduced $\mathrm{Cl} \bullet$ to $\mathrm{Cl}^{-}$, achieving the $\mathrm{Cl}^{-}-\mathrm{Cl} \bullet$ cycle, and promoting $\mathrm{H}_{2}$ generation constantly (Equations (13) and (14)). Moreover, the urea oxidation reaction was a process releasing $\mathrm{H}^{+}$(Equation (15) and Figure S12), and the released $\mathrm{H}^{+}$was reduced and utilized at the cathode. At the same time, $\mathrm{Cl} \bullet$, as a nitrogen removal catalyst, degraded urea to purify urine. The cooperation and sufficient presence of $\mathrm{Cl}^{-}$and urea in urine gives PEC urine purification and $\mathrm{H}_{2}$ energy recovery a great application potential under neutral $\mathrm{pH}$ conditions.

$$
\begin{gathered}
\mathrm{TiO}_{2} / \mathrm{WO}_{3}+\mathrm{hv} \rightarrow \mathrm{h}^{+}+\mathrm{e}^{-} \\
\mathrm{h}^{+}+\mathrm{OH}^{-} \rightarrow \mathrm{HO} \bullet \\
\mathrm{h}^{+}+\mathrm{Cl}^{-} \rightarrow \mathrm{Cl} \bullet \\
\mathrm{HO} \bullet+\mathrm{Cl}^{-} \rightarrow \mathrm{Cl} \bullet+\mathrm{OH}^{-} \\
16 \mathrm{HO} \bullet+\mathrm{CO}\left(\mathrm{NH}_{2}\right)_{2} \rightarrow \mathrm{CO}_{2}+2 \mathrm{NO}_{3}{ }^{-}+9 \mathrm{H}_{2} \mathrm{O}+2 \mathrm{H}^{+} \\
8 \mathrm{HO} \bullet+\mathrm{NH}_{4}{ }^{+} \rightarrow \mathrm{NO}_{3}{ }^{-}+5 \mathrm{H}_{2} \mathrm{O}+2 \mathrm{H}^{+} \\
6 \mathrm{Cl} \bullet+\mathrm{CO}\left(\mathrm{NH}_{2}\right)_{2}+\mathrm{H}_{2} \mathrm{O} \rightarrow \mathrm{N}_{2}+6 \mathrm{Cl}^{-}+\mathrm{CO}_{2}+6 \mathrm{H}^{+} \\
6 \mathrm{Cl} \bullet+2 \mathrm{NH}_{4}^{+} \rightarrow \mathrm{N}_{2}+6 \mathrm{Cl}^{-}+8 \mathrm{H}^{+} \\
2 \mathrm{NO}_{3}{ }^{-}+10 \mathrm{e}^{-}+12 \mathrm{H}^{+} \rightarrow \mathrm{N}_{2}+6 \mathrm{H}_{2} \mathrm{O} \\
\mathrm{NO}_{3}{ }^{-}+8 \mathrm{e}^{-}+10 \mathrm{H}^{+} \rightarrow \mathrm{NH}_{4}{ }^{+}+3 \mathrm{H}_{2} \mathrm{O} \\
2 \mathrm{H}^{+}+2 \mathrm{e}^{-} \rightarrow \mathrm{H}_{2}(\mathrm{On} \mathrm{Cu} \mathrm{NWs} / \mathrm{CF}) \\
\mathrm{Cl}^{-}\left(+\mathrm{h}^{+}\right) \rightarrow \mathrm{Cl}_{\bullet}(+\mathrm{urea}) \rightarrow \mathrm{Cl}^{-} \\
\mathrm{CO}\left(\mathrm{NH}_{2}\right)_{2}+\mathrm{H}_{2} \mathrm{O}-6 \mathrm{e}^{-} \rightarrow \mathrm{CO}_{2}+\mathrm{N}_{2}+6 \mathrm{H}^{+}
\end{gathered}
$$

\subsection{Application of Actual Urine and Stability of System}

In order to investigate the practical application potential of the PEC system, the application of actual urine and the stability of the system were tested. Actual urine was obtained from 5 healthy volunteers, filtered, and diluted to an appropriate concentration for practical application tests, which contained approximately $0.34 \mathrm{~mol} \mathrm{~L}^{-1}$ urea, and $474.9 \mathrm{mmol} \mathrm{L}^{-1} \mathrm{Cl}^{-}$. Figure 6 a showed that $\mathrm{H}_{2}$ generation was $72.73 \mu \mathrm{mol} \mathrm{h}^{-1}$ with actual urine, 2.13 times greater than splitting water, indicating that the presence of actual urine greatly promoted the generation of $\mathrm{H}_{2}$, without the addition of extra alkali. The urine TN removal rate reached $68.36 \%$ after a $2 \mathrm{~h}$ operation under optimal conditions, and after a $4 \mathrm{~h}$ operation, the TN removal rate reached $84.9 \%$ due to a continuous reduction of $\mathrm{NO}_{3}{ }^{-}$on the cathode. The TOC removal rate also reached $38.4 \%$ in $2 \mathrm{~h}$. It indicated that the system could achieve TN removal from actual urine.

The stability of the system, which is limited by the performance of the photoanode and the physical stability of the cathode, directly determines whether the technology can be applied in practice. As such, the operating stability of the system was tested. The experiment was carried out for 4 consecutive cycles, for a total of $8 \mathrm{~h}$. At the same time, the $\mathrm{H}_{2}$ generation and TN removal effect of the anode urea were monitored for 4 cycles. As shown in Figure 6b, in the fourth reaction cycle, the urine TN removal rate still reached $71.34 \%$. Compared with the first cycle, the $\mathrm{H}_{2}$ generation in the fourth cycle dropped only by $6.9 \%$. This shows that the stability of the system is excellent, and that this PEC system has great practical application and development potential. 

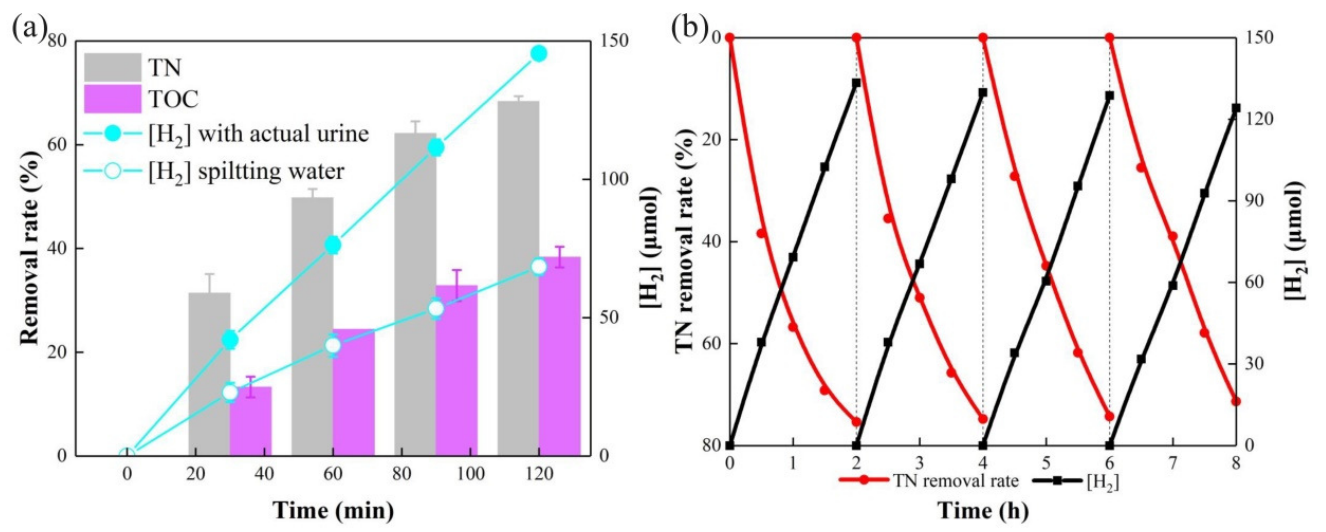

Figure 6. (a) TN and TOC removal rate during $2 \mathrm{~h}$ operation of actual urine, hydrogen generation of splitting water and actual urine; (b) stability test of the PEC system. Conditions: $20 \mathrm{mg} \mathrm{L}^{-1}$ urea; $50 \mathrm{mmol} \mathrm{L}{ }^{-1} \mathrm{Na}_{2} \mathrm{SO}_{4} ; 75 \mathrm{mmol} \mathrm{L}^{-1} \mathrm{NaCl}$; solution $\mathrm{pH}=7$.

\section{Conclusions}

In this work, we developed a self-driving nano PEC system to rapidly purify urine, and simultaneously recover $\mathrm{H}_{2}$ energy from urine in neutral solutions. As the photoanode, $\mathrm{TiO}_{2} / \mathrm{WO}_{3}$ nanosheets generated sufficient $\mathrm{Cl} \bullet$ to oxidize the urea. $\mathrm{Cu}$ NWs/CF, which had a large specific surface area and great conductivity, was appropriate for the hydrogen evolution reaction. The high selectivity of $\mathrm{Cl} \bullet$ sped up the TN removal process. Solar panels allowed for the system to only be driven by solar energy. A total of $75.3 \%$ of TN was removed within $2 \mathrm{~h}$, and $90.2 \%$ of TN was removed within $4 \mathrm{~h}$. The addition of actual urine doubled the $\mathrm{H}_{2}$ generation. This system achieved excellent $\mathrm{H}_{2}$ energy recovery and simultaneous $\mathrm{TN}$ removal from urine under neutral $\mathrm{pH}$ conditions.

Supplementary Materials: The following are available online at https:/ / www.mdpi.com/article/ 10.3390/nano11112777/s1, Table S1: The composition of synthetic urine, Table S2: The recipes of sample solution in the blank and treatment group, Figure S1: (a) Chopped LSV curvces of the $\mathrm{WO}_{3}$ and $\mathrm{TiO}_{2} / \mathrm{WO}_{3}$ photoanode in $0.1 \mathrm{~mol} \mathrm{~L}{ }^{-1} \mathrm{Na}_{2} \mathrm{SO}_{4} ;(\mathrm{b})$ photo-response current and stability of $\mathrm{WO}_{3}$ and $\mathrm{TiO}_{2} / \mathrm{WO}_{3}$ electrodes, Figure S2: UV-vis absorption spectrum of the $\mathrm{TiO}_{2} / \mathrm{WO}_{3}$ and $\mathrm{WO}_{3}$ photoanodes, Figure S3: (a) XRD patterns of $\mathrm{FTO}, \mathrm{WO}_{3}, \mathrm{TiO}_{2} / \mathrm{WO}_{3}$ electrodes; (b) core-level XPS spectra of Ti2p of $\mathrm{TiO}_{2} / \mathrm{WO}_{3}$ electrode, Figure S4: TEM image of $\mathrm{Cu}$ nanowire, Figure S5: Surface roughness of $\mathrm{CF}$ (a) and $\mathrm{Cu}$ NWs/CF (b) using confocal laser scanning microscope, Figure S6: (a) XRD patterns of $\mathrm{CF}, \mathrm{Cu}(\mathrm{OH})_{2} \mathrm{NWs} / \mathrm{CF}, \mathrm{Cu}$ NWs/CF electrode; (b) core-level XPS spectra of Cu2p of $\mathrm{Cu}$ NWs/CF electrode; (c) core-level XPS spectra of Cu2p of CF electrode, Figure S7: (a) Nyquist plots of CF and $\mathrm{Cu}$ NWs/CF at $0.6 \mathrm{~V}$ potential (vs. Ag/AgCl); (b) LSV curves of CF and Cu NWs/CF, Figure S8: The rate curves and kinetic curves of urea removal in optimal conditions, Figure S9: TN and TOC removal rate during $4 \mathrm{~h}$ operation, Figure S10: The concentration of ammonia-N, nitrate-N, nitrite-N and urea during the reaction process, Figure S11: Nitrate reduction rate constant of different cathodes, Figure S12: $\mathrm{pH}$ value, urea removal rate and $\mathrm{H}_{2}$ generation over time during reaction. Refs. [51-53] are cited in the Supplementary Materials.

Author Contributions: Conceptualization, P.W. and B.Z. (Baoxue Zhou); Data curation, J.L. and J.B.; Investigation, P.W., J.L. and Y.X.; Methodology, P.W.; Project administration, B.Z. (Baoxue Zhou); Supervision, J.L. and B.Z. (Baoxue Zhou); Validation, P.W., L.Z. and B.Z. (Bo Zhang); Visualization, P.W., C.Z. and Y.Z.; Writing-original draft, P.W.; Writing-review \& editing, B.Z. (Baoxue Zhou). All authors have read and agreed to the published version of the manuscript.

Funding: This research was funded by the National Natural Science Foundation of China (Grant No. 22178220, No. 21875139, No. 21776177), the National Key Research and Development Program of China (Grant 2018YFE0122300), and Shanghai International Science and Technology Cooperation Fund Project (Grant No. 18520744900).

Institutional Review Board Statement: Not applicable. 
Informed Consent Statement: Informed consent was obtained from all subjects involved in the study.

Conflicts of Interest: The authors declare no conflict of interest.

\section{References}

1. Glibert, P.M.; Harrison, J.; Heil, C.; Seitzinger, S. Escalating worldwide use of urea-A global change contributing to coastal eutrophication. Biogeochemistry 2006, 77, 441-463. [CrossRef]

2. Wang, G.; Ling, Y.; Lu, X.; Wang, H.; Qian, F.; Tong, Y.; Li, Y. Solar driven hydrogen releasing from urea and human urine. Energy Environ. Sci. 2012, 5, 8215-8219. [CrossRef]

3. Rollinson, A.N.; Jones, J.; Dupont, V.; Twigg, M.V. Urea as a hydrogen carrier: A perspective on its potential for safe, sustainable and long-term energy supply. Energy Environ. Sci. 2011, 4, 1216-1224. [CrossRef]

4. Larsen, T.A.; Alder, A.C.; Eggen, R.I.; Maurer, M.; Lienert, J. Source separation: Will we see a paradigm shift in wastewater handling? Environ. Sci. Technol. 2009, 43, 6121-6125. [CrossRef] [PubMed]

5. Spångberg, J.; Tidåker, P.; Jönsson, H. Environmental impact of recycling nutrients in human excreta to agriculture compared with enhanced wastewater treatment. Sci. Total Environ. 2014, 493, 209-219. [CrossRef]

6. Wilsenach, J.; Van Loosdrecht, M.C. Effects of separate urine collection on advanced nutrient removal processes. Environ. Sci. Technol. 2004, 38, 1208-1215. [CrossRef] [PubMed]

7. Wilsenach, J.; Schuurbiers, C.; Van Loosdrecht, M. Phosphate and potassium recovery from source separated urine through struvite precipitation. Water Res. 2007, 41, 458-466. [CrossRef]

8. Dutta, S. A review on production, storage of hydrogen and its utilization as an energy resource. J. Ind. Eng. Chem. 2014, 20, 1148-1156. [CrossRef]

9. Boggs, B.K.; King, R.L.; Botte, G.G. Urea electrolysis: Direct hydrogen production from urine. Chem. Commun. $2009,4859-4861$. [CrossRef]

10. Yan, X.; Hu, Q.-T.; Wang, G.; Zhang, W.-D.; Liu, J.; Li, T.; Gu, Z.-G. NiCo layered double hydroxide/hydroxide nanosheet heterostructures for highly efficient electro-oxidation of urea. Int. J. Hydrogen Energy 2020, 45, 19206-19213. [CrossRef]

11. Gan, J.; Rajeeva, B.B.; Wu, Z.; Penley, D.; Zheng, Y. Plasmon-enhanced hierarchical photoelectrodes with mechanical flexibility for hydrogen generation from urea solution and human urine. J. Appl. Electrochem. 2020, 50, 63-69. [CrossRef]

12. Liu, D.; Liu, T.; Zhang, L.; Qu, F.; Du, G.; Asiri, A.M.; Sun, X. High-performance urea electrolysis towards less energy-intensive electrochemical hydrogen production using a bifunctional catalyst electrode. J. Mater. Chem. A 2017, 5, 3208-3213. [CrossRef]

13. Xie, J.; Gao, L.; Cao, S.; Liu, W.; Lei, F.; Hao, P.; Xia, X.; Tang, B. Copper-incorporated hierarchical wire-on-sheet $\alpha-\mathrm{Ni}(\mathrm{OH})_{2}$ nanoarrays as robust trifunctional catalysts for synergistic hydrogen generation and urea oxidation. J. Mater. Chem. A 2019, 7 , 13577-13584. [CrossRef]

14. Song, M.; Zhang, Z.; Li, Q.; Jin, W.; Wu, Z.; Fu, G.; Liu, X. Ni-foam supported Co(OH)F and Co-P nanoarrays for energy-efficient hydrogen production via urea electrolysis. J. Mater. Chem. A 2019, 7, 3697-3703. [CrossRef]

15. Urbańczyk, E.; Sowa, M.; Simka, W. Urea removal from aqueous solutions-A review. J. Appl. Electrochem. 2016, 46, 1011-1029. [CrossRef]

16. Xie, D.; Li, C.; Tang, R.; Lv, Z.; Ren, Y.; Wei, C.; Feng, C. Ion-exchange membrane bioelectrochemical reactor for removal of nitrate in the biological effluent from a coking wastewater treatment plant. Electrochem. Commun. 2014, 46, 99-102. [CrossRef]

17. Lan, R.; Tao, S.; Irvine, J.T. A direct urea fuel cell-power from fertiliser and waste. Energy Environ. Sci. 2010, 3, 438-441. [CrossRef]

18. Ra, J.; Yoom, H.; Son, H.; Hwang, T.-M.; Lee, Y. Transformation of an amine moiety of atenolol during water treatment with chlorine/UV: Reaction kinetics, products, and mechanisms. Environ. Sci. Technol. 2019, 53, 7653-7662. [CrossRef]

19. Deng, L.; Huang, C.-H.; Wang, Y.-L. Effects of combined UV and chlorine treatment on the formation of trichloronitromethane from amine precursors. Environ. Sci. Technol. 2014, 48, 2697-2705. [CrossRef]

20. Zhang, X.; Li, W.; Blatchley III, E.R.; Wang, X.; Ren, P. UV/chlorine process for ammonia removal and disinfection by-product reduction: Comparison with chlorination. Water Res. 2015, 68, 804-811. [CrossRef]

21. Zheng, W.; Zhu, L.; Liang, S.; Ye, J.; Yang, X.; Lei, Z.; Yan, Z.; Li, Y.; Wei, C.; Feng, C. Discovering the Importance of ClO• in a Coupled Electrochemical System for the Simultaneous Removal of Carbon and Nitrogen from Secondary Coking Wastewater Effluent. Environ. Sci. Technol. 2020, 54, 9015-9024. [CrossRef]

22. Li, F.; Peng, X.; Liu, Y.; Mei, J.; Sun, L.; Shen, C.; Ma, C.; Huang, M.; Wang, Z.; Sand, W. A chloride-radical-mediated electrochemical filtration system for rapid and effective transformation of ammonia to nitrogen. Chemosphere 2019, 229, 383-391. [CrossRef] [PubMed]

23. Zhang, Y.; Li, J.; Bai, J.; Li, X.; Shen, Z.; Xia, L.; Chen, S.; Xu, Q.; Zhou, B. Total organic carbon and total nitrogen removal and simultaneous electricity generation for nitrogen-containing wastewater based on the catalytic reactions of hydroxyl and chlorine radicals. Appl. Catal. B 2018, 238, 168-176. [CrossRef]

24. Ji, Y.; Bai, J.; Li, J.; Luo, T.; Qiao, L.; Zeng, Q.; Zhou, B. Highly selective transformation of ammonia nitrogen to $\mathrm{N}_{2}$ based on a novel solar-driven photoelectrocatalytic-chlorine radical reactions system. Water Res. 2017, 125, 512-519. [CrossRef] [PubMed]

25. Xiao, S.; Qu, J.; Zhao, X.; Liu, H.; Wan, D. Electrochemical process combined with UV light irradiation for synergistic degradation of ammonia in chloride-containing solutions. Water Res. 2009, 43, 1432-1440. [CrossRef] [PubMed]

26. Garcia-Segura, S.; Brillas, E. Applied photoelectrocatalysis on the degradation of organic pollutants in wastewaters. J. Photochem. Photobiol. C 2017, 31, 1-35. [CrossRef] 
27. Li, S.; Li, M.; Ni, Y. Grass-like Ni/Cu nanosheet arrays grown on copper foam as efficient and non-precious catalyst for hydrogen evolution reaction. Appl. Catal. B 2020, 268, 118392. [CrossRef]

28. Tian, Y.; Song, Y.; Liu, J.; Ji, J.; Wang, F. MoS $\mathrm{x}$ Coated Copper Nanowire on Copper Foam as A Highly Stable Photoelectrode for Enhanced Photoelectrocatalytic Hydrogen Evolution Reaction via. Plasmon-Induced Hot Carriers. Chem. Eng. J. 2020, 398, 125554. [CrossRef]

29. Sivasakthi, P.; Premlatha, S.; Bapu, G.R.; Chandrasekaran, M. Pulse electrodeposited Ni-CeO $\mathrm{C}_{2}$ doped nanocomposite on copper foam as an electrocatalysts for hydrogen evolution reaction. Int. J. Hydrogen Energy 2017, 42, 4741-4750. [CrossRef]

30. Yang, L.; Li, L.; Yang, Y.; Zhang, G.; Gong, L.; Jing, L.; Fu, H.; Shi, K. Facile synthesis of Cu/Cu $\mathrm{x}_{\mathrm{O}}$ nanoarchitectures with adjustable phase composition for effective $\mathrm{NO}_{x}$ gas sensor at room temperature. Mater. Res. Bull. 2013, 48, 3657-3665. [CrossRef]

31. Yu, L.; Zhou, H.; Sun, J.; Qin, F.; Yu, F.; Bao, J.; Yu, Y.; Chen, S.; Ren, Z. Cu nanowires shelled with NiFe layered double hydroxide nanosheets as bifunctional electrocatalysts for overall water splitting. Energy Environ. Sci. 2017, 10, 1820-1827. [CrossRef]

32. Wang, Y.; Zhou, W.; Jia, R.; Yu, Y.; Zhang, B. Unveiling the Activity Origin of a Copper-based Electrocatalyst for Selective Nitrate Reduction to Ammonia. Angew. Chem. Int. Edit. 2020, 132, 5388-5392. [CrossRef]

33. Zeng, Q.; Bai, J.; Li, J.; Li, L.; Xia, L.; Zhou, B.; Sun, Y. Highly-stable and efficient photocatalytic fuel cell based on an epitaxial $\mathrm{TiO}_{2} / \mathrm{WO}_{3} / \mathrm{W}$ nanothorn photoanode and enhanced radical reactions for simultaneous electricity production and wastewater treatment. Appl. Energy 2018, 220, 127-137. [CrossRef]

34. Zeng, T.; Yu, M.; Zhang, H.; He, Z.; Chen, J.; Song, S. Fe/Fe 3 C@N-doped porous carbon hybrids derived from nano-scale MOFs: Robust and enhanced heterogeneous catalyst for peroxymonosulfate activation. Catal. Sci. Technol. 2017, 7, 396-404. [CrossRef]

35. Ali, S.; Li, Z.; Chen, S.; Zada, A.; Khan, I.; Khan, I.; Ali, W.; Shaheen, S.; Qu, Y.; Jing, L. Synthesis of activated carbon-supported $\mathrm{TiO}_{2}$-based nano-photocatalysts with well recycling for efficiently degrading high-concentration pollutants. Catal. Today 2019, 335, 557-564. [CrossRef]

36. Zeng, Q.; Bai, J.; Li, J.; Zhou, B.; Sun, Y. A low-cost photoelectrochemical tandem cell for highly-stable and efficient solar water splitting. Nano Energy 2017, 41, 225-232. [CrossRef]

37. Zeng, Q.; Li, J.; Bai, J.; Li, X.; Xia, L.; Zhou, B. Preparation of vertically aligned $\mathrm{WO}_{3}$ nanoplate array films based on peroxotungstate reduction reaction and their excellent photoelectrocatalytic performance. Appl. Catal. B 2017, 202, 388-396. [CrossRef]

38. Zhang, Y.; Li, J.; Bai, J.; Shen, Z.; Li, L.; Xia, L.; Chen, S.; Zhou, B. Exhaustive conversion of inorganic nitrogen to nitrogen gas based on a photoelectro-chlorine cycle reaction and a highly selective nitrogen gas generation cathode. Environ. Sci. Technol. 2018, 52, 1413-1420. [CrossRef]

39. Kalanur, S.S.; Hwang, Y.J.; Chae, S.Y.; Joo, O.S. Facile growth of aligned $\mathrm{WO}_{3}$ nanorods on $\mathrm{FTO}$ substrate for enhanced photoanodic water oxidation activity. J. Mater. Chem. A 2013, 1, 3479-3488. [CrossRef]

40. Zhou, C.; Bai, J.; Zhang, Y.; Li, J.; Li, Z.; Jiang, P.; Fang, F.; Zhou, M.; Mei, X.; Zhou, B. Novel 3D Pd-Cu(OH) $2 / \mathrm{CF}$ cathode for rapid reduction of nitrate-N and simultaneous total nitrogen removal from wastewater. J. Hazard. Mater. 2021, 401, 123232. [CrossRef]

41. Peng, Q.; Zhao, H.; Qian, L.; Wang, Y.; Zhao, G. Design of a neutral photo-electro-Fenton system with 3D-ordered macroporous $\mathrm{Fe}_{2} \mathrm{O}_{3}$ / carbon aerogel cathode: High activity and low energy consumption. Appl. Catal. B 2015, 174, 157-166. [CrossRef]

42. Nagy, D.; Nagy, D.; Szilágyi, I.M.; Fan, X. Effect of the morphology and phases of $\mathrm{WO}_{3}$ nanocrystals on their photocatalytic efficiency. RSC Adv. 2016, 6, 33743. [CrossRef]

43. Bayati, M.; Golestani-Fard, F.; Moshfegh, A. Visible photodecomposition of methylene blue over micro arc oxidized $\mathrm{WO}_{3}-$ loaded $\mathrm{TiO}_{2}$ nano-porous layers. Appl. Catal. A 2010, 382, 322-331. [CrossRef]

44. Wang, X.; Zhu, M.; Zeng, G.; Liu, X.; Fang, C.; Li, C. A three-dimensional Cu nanobelt cathode for highly efficient electrocatalytic nitrate reduction. Nanoscale 2020, 12, 9385-9391. [CrossRef] [PubMed]

45. Liu, Q.; Shen, Y.; Song, S.; He, Z. Enhanced electrocatalytic hydrodechlorination of 2, 4-dichlorophenoxyacetic acid by a $\mathrm{Pd}-\mathrm{Co}_{3} \mathrm{O}_{4} / \mathrm{Ni}$ foam electrode. RSC Adv. 2019, 9, 12124-12133. [CrossRef]

46. He, D.; Xing, S.; Sun, B.; Cai, H.; Suo, H.; Zhao, C. Design and construction of three-dimensional flower-like CuO hierarchical nanostructures on copper foam for high performance supercapacitor. Electrochim. Acta 2016, 210, 639-645. [CrossRef]

47. Fang, F.; Zhang, Y.; Bai, J.; Li, J.; Mei, X.; Zhou, C.; Zhou, M.; Zhou, B. Efficient urine removal, simultaneous elimination of emerging contaminants, and control of toxic chlorate in a photoelectrocatalytic-chlorine system. Environ. Pollut. 2020, $267,115605$. [CrossRef]

48. Jiang, Z.; Wang, L.; Lei, J.; Liu, Y.; Zhang, J. Photo-Fenton degradation of phenol by CdS/rGO/Fe $\mathrm{Fe}^{2+}$ at natural $\mathrm{pH}$ with in situ-generated $\mathrm{H}_{2} \mathrm{O}_{2}$. Appl. Catal. B 2019, 241, 367-374. [CrossRef]

49. Zhang, Y.; Li, J.; Bai, J.; Li, L.; Chen, S.; Zhou, T.; Wang, J.; Xia, L.; Xu, Q.; Zhou, B. Extremely Efficient Decomposition of Ammonia $\mathrm{N}$ to $\mathrm{N}_{2}$ Using $\mathrm{ClO} \bullet$ from Reactions of $\mathrm{HO} \bullet$ and $\mathrm{HOCl}$ Generated in Situ on a Novel Bifacial Photoelectroanode. Environ. Sci. Technol. 2019, 53, 6945-6953. [CrossRef]

50. Li, X.; Bai, J.; Li, J.; Zhang, Y.; Shen, Z.; Qiao, L.; Xu, Q.; Zhou, B. Efficient TN removal and simultaneous TOC conversion for highly toxic organic amines based on a photoelectrochemical-chlorine radicals process. Catal. Today 2019, 335, 452-459. [CrossRef]

51. McCurdy, D.; Lin, Z.; Inn, K.; Bell III, R.; Wagner, S.; Efurd, D.; Steiner, R.; Duffy, C.; Hamilton, T.; Brown, T. Second interlaboratory comparison study for the analysis of $239 \mathrm{Pu}$ in synthetic urine at the microBq $(-100 \mathrm{aCi})$ level by mass spectrometry. J. Radioanal. Nucl. Chem. 2005, 263, 447-455. [CrossRef] 
52. Saetta, D.; Boyer, T.H. Mimicking and inhibiting urea hydrolysis in nonwater urinals. Environ. Sci. Technol. 2017, 51, 13850-13858. [CrossRef] [PubMed]

53. Ray, H.; Perreault, F.; Boyer, T.H. Urea recovery from fresh human urine by forward osmosis and membrane distillation (FO-MD). Environ. Sci. Water Res. Technol. 2019, 5, 1993-2003. [CrossRef] 